\title{
Development of Tennis Serve Learning Models Based on Multiple Training
}

\author{
Surya Rezeki Sitompul ${ }^{1, *}$, Firmansyah Dlis ${ }^{1}$, Hernawan $^{1}$, Anisa Sholihamia ${ }^{1}$, \\ Galang Pakarti Mahardika ${ }^{2}$
}

\author{
${ }^{1}$ Department of Sport Education, State University of Jakarta, Jakarta, 13220, East Jakarta, Indonesia \\ ${ }^{2}$ Department of Sport Education, University Muhammadiyah Jakarta, Banten, 15419, South Tangerang, Indonesia
}

Received September 22, 2020; Revised November 27, 2020; Accepted December 22, 2020

\begin{abstract}
Cite This Paper in the following Citation Styles
(a): [1] Surya Rezeki Sitompul, Firmansyah Dlis, Hernawan, Anisa Sholihamia, Galang Pakarti Mahardika, "Development of Tennis Serve Learning Models Based on Multiple Training," International Journal of Human Movement and Sports Sciences, Vol. 8, No. 6A, pp. 11-15, 2020. DOI: 10.13189/saj.2020.080702.
\end{abstract}

(b): Surya Rezeki Sitompul, Firmansyah Dlis, Hernawan, Anisa Sholihamia, Galang Pakarti Mahardika (2020). Development of Tennis Serve Learning Models Based on Multiple Training. International Journal of Human Movement and Sports Sciences, 8(6A), 11-15. DOI: 10.13189/saj.2020.080702.

Copyright $\odot 2020$ by authors, all rights reserved. Authors agree that this article remains permanently open access under the terms of the Creative Commons Attribution License 4.0 International License

\begin{abstract}
This study aims at developing multiple-training-based learning model to improve technical capabilities of tennis serve of the students of the Faculty of Sports, Medan State University. This study used research and development method propounded by Borg and Gall. Based on the test result that was taken and applied to small and big samples, it is revealed that the multiple-training-based learning model can be implemented to improve the skills of tennis serve technique of the students of the Faculty of Sports Science, Medan State University. The subjects of this research and development study were 38 students of Physical Education, Sports, Health, and Recreation Department, Faculty of Sports, Medan State University, North Sumatera, Indonesia. The study found that the effectiveness level of the old teaching model is $66 \%$ out of the expected level criteria, while that of the new learning model reaches $96 \%$. It means that the effectiveness level improves for $30 \%$. Accordingly, it can be concluded that: (1) the multiple-training-based learning models can improve the serve technique and the serve result, and (2) the learning model is more effective and efficient in increasing students' participation in the instructional process.
\end{abstract}

Keywords Learning Models, Tennis Court, Serve, Multiple Training

\section{Introduction}

Tennis is one of the sport branches of small ball game which can be played single or double. The game is applied by hitting the ball using a racket to the opponent (s)' court bounded by a net. Like other sports, tennis demands some basic skills every tennis player must have. In the lawn tennis game, technique and physical condition are the determining factors for success. The basic techniques in the tennis game are the forehand, backhand, drive, service, slice, spin, dropshot, smash, lob, passing shot and volley [1]. In modern tennis game, world-class players have standardized-serve and return as they may have significant impact on the outcome of the game.

There are five basic techniques that must be mastered by a tennis player. They are serve, groundstroke, volley, smash and lob. Groundstroke shots include drive, slice, dropshot and half volley. There are three types of strokes; they are groundstroke, volley, and overhead stroke. Groundstroke is where the player hits after the ball bounces once on the court. Techniques that are classified as a type of groundstrokes are forehand drive, drop shot, and half-volley. Volley technique is where the player hits the ball before it bounces on the court. Here, the racket is not swung over the head. Volley shots consist of volley, drives and lob. On the other hand, overhead strokes are serving and smash.

Serve is defined as the opening shot of a point. 
According to the rules, player has the right to do a second trial if it fails in the first, To avoid the failure, in the first serve, the ball is usually thrown into the air to reach the maximum strength and spin, and almost always toward the weaker side or toward the opponent's body [2]. One of the most important aspects in the lawn tennis game is the service. Factors affecting service, besides the body's physical condition and position, are angle of movement and force. Good body position, right angle of movement and strong force will result in a good service [1].

There are three types of serves that can be used. They are (1) flat serve: the shot in which the ball is hit almost without spin (minimal spin). (2) slice serve: the shot in which the ball is hit with a sidespin, transmitted by brushing the ball from right to left (for right-handed player) [3]. Topspin serve is hit with combination of double spin, side and forward, transmitted by brushing the ball from the back to the top and right (3) twist serve: originally known as the "American twist", a special kind of slices serve where the ball reacts differently after bouncing on the field because it has more topspin than sidespin rotation [4].

When twist serve is executed properly, the ball bounces in the opposite direction of the slice serve. In all types of serves, especially in specific cases, the most commonly used grips are continental and eastern backhand [5]. As explained by the references above, it can be concluded that there are few types of serves based on its application and used in tennis game.

Based on the authors' observation supported by statements from the lecturer of the tennis course at Physical Education, Sports, Health, and Recreation Department, Faculty of Sports, Medan State University, there are some shortcomings in the process of learning tennis serve that negatively affect the achievement of the desired results. The results showed that: (1) the students tend to get bored and less active in following the learning activities, (2) the students do not understand the purpose of learning, (3) the students lack mastery of correct movements techniques, (4) students do not enjoy the process of learning (5) the students feel bored and cannot make sense of the benefits from the learning activities.

These evidences are in line with the students' average scores in tennis technique skills in which many students obtained score C or even E. Accordingly, motivation and repetition in training and learning must be possessed by the students. Motivation is booster that changes the energy within a person into real activity to achieve certain goals in the target. Motivation is an aspect that is needed to achieve the goal(s) in learning. Motivation has been defined as the process whereby goal-directed activities are initiated and sustained. In expectancy-value theory, motivation is a function of the expectation of success and perceived value. As the quote says, the use of literature on teaching and learning also determine the effectiveness of students' motivation and interest. On the other hand, certain patterns can improve fitness training elements and also increase muscle development [6]

Therefore, to improve muscle fitness and development, special exercise and repetition are required. It has to be said that an increase in creativity and innovation in the educational processes in sports education and health especially in field tennis items. Success in the application of training models in increased success does much to have a close effect on solving the learning difficulties [7].

Development research is a pragmatic form of research that provides a way to test theories and legalize habits that have been perpetuated through academic traditions. In addition, development research is also a way to generate procedures, techniques, and tools based on analysis, methodists of a problem [8].

All in all, the research and development is a study which focuses on the creation of an effective product in which the process includes the needs analysis, product development, and product testing. The research that is developed in this study is tennis serve learning models for students of Physical Education, Sports, Health, and Recreation Department, Faculty of Sports, Medan State University.

\subsection{Learning Model}

Learning model is one of important components in supporting learning process [9]. Therefore, it is needed to conduct a development in its empowering and organizing, to achieve desired goals. Models are description of a reality reflection which will be done as stated "models by definition and a reflection of reality-temporary stand-ins for something more specific and real; model are helpful in explaining that may be difficult to describe; a model may illustrate a process; a model may be a representation of something". Learning models can also be linked to the whole course of good learning starting from the beginning of learning to the end of learning that involves aspects of the facilities used directly and indirectly. Curriculum materials, materials design and petfor learning that teachers use become learning tools [10].

Model can also be interpreted as a plan or pattern that is used to compile the curriculum, organize teaching materials and give instructions to the teachers in the implementation of teaching and learning activities in the classroom. The classroom activities are implemented in two types of schools; private and public institutions which are parts of the public education system as Slater and Ravid reveal that schools and universities, both private and public are parts of the public education system.

The development of learning model is one form of applying a system approach in learning activities which in fact is a systematic process that generates a learning system that is ready to be used appropriately. Learning 
model is a series of components of an integrated learning strategy. The strategy consists of several components such as: (1) the phasing and sequence of contents of the material; (2) the use of examples; (3) the use of practice; and (4) the use of different strategies.

Stating a model-based approach for physical education uses the application of various pedagogical models, each with unique and distinctive learning model results and aligning learning outcomes with teaching strategies and learning materials where the use of each is non-negotiable in terms of what is done by teachers and students for carrying out the model with full confidence. Advances in educational program evaluation contribute significantly to curriculum thought, as qualitative approaches were added to the standard of quantitative styles. As the quotation says, then advances in the evaluation of learning have important contribution to the development of the students themselves saying that the logic behind the model-based approach is that the use of different work modules, each with different features and special learning outcomes, can meet various objectives [11].

It also reveals that the model operates on two levels; curricular level and instructional level. At the curricular level, the model approach provides the program with mission, main content, identity and infrastructure all for the purpose of allowing more students to achieve learning outcomes of long-term priorities [12]. While at the instructional level, the model approach is used to promote the study in a short duration that aims to align the learning outcomes. Finally, from the explanation in a wide range of experts above, it can be concluded that the learning model is a pattern or step that includes analysis, development, and evaluation of learning outcomes in which the purpose is to make it easier for the students be able to achieve optimal learning outcomes and master tennis serve techniques.

\subsection{Flat Serve Technique}

Serve is the first shot made to start a game to obtain points. Serve is executed by hitting the ball to the opposite court over the net by crossing and falling on the opponent's service box [13]. The flat serve is the basic service motion. The setup for this serve is the foundation for the more advanced serves. When placed accurately, the flat serve often results in a service winner, a weak return, or an ace! The tradeoff is that it offers less control.

A flat service is the most effective of the four services, and the effect or characteristic of these services' blows does not create a rotary effect, in order to prevent the opponent from recapping the ball in order to create a distraction, if the technical treatment is done properly and the time, speed and locating of the ball, then the service is highly effective [14].

Flat serve is the hardest and most powerful serve shot compared to other serves. Accordingly, it is commonly called cannon ball serve. The ball produced from this serve shot has almost no spin. The ball course on flat serve is in a straight line and the produced ball bounce is normal. For tall tennis players, flat serve becomes the first choice in serving. Suggesting that there are four steps in the executing flat serve, they ate racket grip, toss Ball, impact on the ball, and advanced Movement. Above all, the grip is a key success factor. In addition, it is generally mentioned that the cause for the absence of the optimal impact on the ball on the racket strings is the wrong grip [3].

Based on the elaboration of the explanations of these theories, it can be concluded that the flat serve tends to produce strong and powerful shot without making the ball spinning that the ball course movement is straight without any changes. [3]

\section{Materials and Methods}

This study used Research and Development (R \& D), in development research, there are two fundamental differences, but these terms guided at the same value, and the purpose of the development research process makes both in increase of theoretical contributions and increase of practical contributions [15]. In the contribution of educational development research for example, to quote 2008 puslitjaknov research there were 3 components of development research in the education consisting of (1) development model, (2) development procedures and (3) development model or product testing.

Suggesting that the study is conducted through these following steps: (1) conducting research and gathering information; (2) planning that includes defining skills, formulating objectives, determining the order of teaching, and testing on small scale; (3) developing initial product forms such as preparing teaching materials, preparing handbooks and evaluating equipment or media; (4) carrying out initial field test. This test was given to 6-12 subjects; (5) revising the main products in accordance with the advice from the results of the initial field test; (6) carrying out the main field test involving 30-100 subjects; (7) revising the product based on the suggestions and the results from the main field test; (8) conducting field trials to 30-200 subjects; (9) revising the final product; (10) writing a report about the product in the journal in collaboration with publisher (s) who can distribute commercially.

In this study the method of research analysis refers to qualitative approaches as used to supplement the goal of the first, while the quantitative approach is used to unblock the second goal, with a design for experimental research pre-test and postest design). Researchers observe a pre-test (o1), which is treated by maintenance techniques (x), followed by observation or post-test (o2). find an average score of pre-test and post-test results, and 
then compare them through statistical methods (uji-t) to see if there was a significant impact on the use of the learning model. Other data in the form of field records and documentaries should be present in the main test so that feedback (feedback) can be used for the improvements and improvements of the learning model in the next development up to the optimization that is the ultimate form for use.

\section{Conclusions}

Based on the data obtained, the results of small group trials, field tests and discussion of research results can be concluded that:

a). Development of these tennis serve learning models helps the lecturer in implementing or carrying out effective and efficient learning process.

b). Through the learning models provided, learning outcomes of tennis serve on student of Physical Education, Sports, Health, and Recreation Department, Faculty of Sports, Medan State University improves and it helps the lecturer in implementing or carrying out the learning process.

The implementation of the learning models that have been developed is considered to make a significant contribution both to the learning process and to the learning outcomes effectively and efficiently and to motivate children to play an active role in the learning process with the steps that are stude-nts to understand. The final result of this study would be in the form of a product (video) completed with learning specifications as well as facilities and infrastructure.

The results of tennis serve learning models development for students of Physical Education, Sports, Health, and Recreation Department, Faculty of Sports, Medan State University were written in the form of a script (storyboard script) that provides various forms of tennis serve learning models, packaged in modified form of learning models with customized approach from the steps in tennis serve techniques that will make it easy to apply in the field. Table 1 shows the learning success achieved through the learning models development.

Table 1 shows that the amount of data obtained are 520 . Thus the effectiveness of the old learning model as a whole is $520: 760=0.68$ or $68 \%$ of the expected criteria. Test results of the old learning models are $68 \%$ or only 24 students passed the learning target, while $32 \%$ of it, or 14 students, did not pass the target. Furthermore, it also reveals that the amount of data obtained is 760 which means the effectiveness of the overall new learning model development is $600: 760=0.78$ or $78 \%$ of the expected criteria. The test results of learning using new learning models development of tennis serve are $92 \%$ or 35 students passed the learning target. While $8 \%$ of them, or
3 students, did not pass the target. The next step is to calculate the psychomotor t-test, to decide whether the difference is significant or not. Then the value of the $\mathrm{t}$-count needs to be compared to the value of $\mathrm{t}$-table at $\mathrm{dk}$ $\mathrm{n}-2=36$.

Table 1. Comparison Table of Assessment Results of Old Learning Model (s) and New Learning Models

\begin{tabular}{|c|c|c|}
\hline Conventional Method & Rated Aspect & $\begin{array}{c}\text { New Learning } \\
\text { Method }\end{array}$ \\
\hline 122 & Ready position & 148 \\
\hline 104 & Ball toss & 116 \\
\hline 95 & Racket pull & 102 \\
\hline 109 & Impact ball & 135 \\
\hline 90 & $\begin{array}{c}\text { Continued } \\
\text { movement }\end{array}$ & 99 \\
\hline 520 & Amount & 600 \\
\hline 0.68 & Average & 0.78 \\
\hline
\end{tabular}

Based on the attachment, the value in the $t$ distribution is that, if $\mathrm{dk} 36$, for one-tail test with a standard error of $5 \%$, then the value of $t$ table $=1.685$. If the value of $t$ count falls to the reception area of Ha, then Ha stating that the new learning methods are better than the old learning methods is accepted. Based on the calculation, it turned out that $t$ count is -17.29 and falls on the acceptance of $\mathrm{Ha}$ or rejection of Ho. Accordingly, it can be concluded that there is significant differences on the effectiveness between the old and new teaching approaches.

Comparison between the results of tests on serve ability using the conventional methods and learning model development methods obtained results of Precision/Accuracy 458: 586 and Power 324: 443, with a total score of 769: 1029. The techniques used to determine and make a decision, whether the difference is significant or not, comparing the value of $t$ count with the value of $t$ table at $\mathrm{dk} n-2=36$.

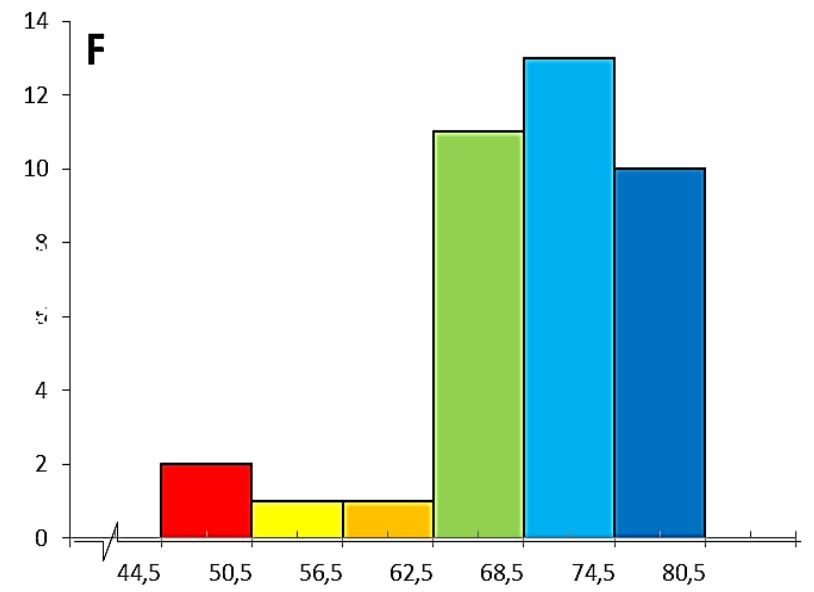

Figure 1. Histogram image of learning outcomes of conventional learning methods 


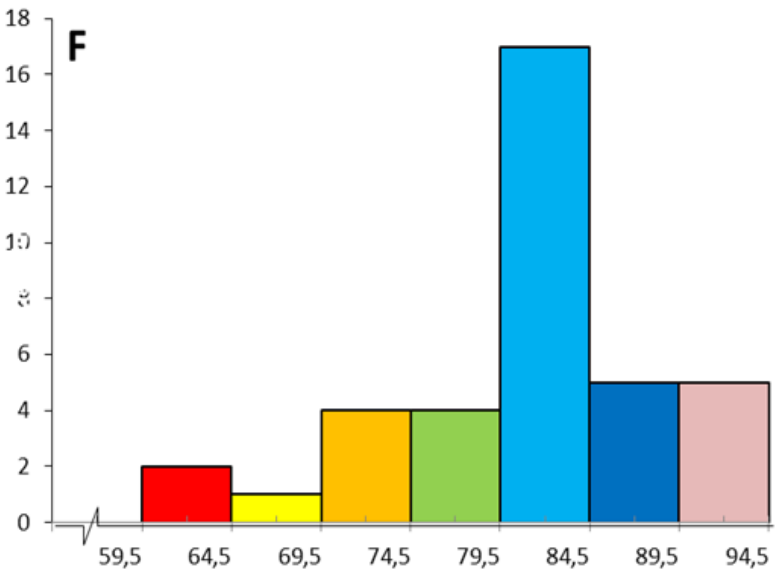

Figure 2. Histogram image of learning outcomes of new learning methods

Based on the attachment, the values in the $t$ distribution is that, if $\mathrm{dk} 36$, for one-tail test with a standard error of $5 \%$, then the value of $t$ table $=1.685$. If the value of $t$ count falls to the reception area $\mathrm{Ha}$, Ha stating that the new teaching approach is better than the old teaching approach is accepted.

Based on the calculation, it turned out that $t$ count is 19.72 and falls on the acceptance of Ho or rejection of Ha. Thus it can be concluded that there is no significant difference between the new learning methods and the old learning methods.

\section{Acknowledgments}

The authors would like to thank the dean of Faculty of Sports of Medan State University, Sabarudin Daulay, M.Pd and the lecturers teaching Tennis, David, M.Pd, and our supervisors Prof. Dr. Moch. Asmawi, M.Pd and Dr. Ramdhan Pelana, M.Pd for all the constructive inputs and suggestions during and after the accomplishment of this study.

\section{REFERENCES}

[1] Amir, N. Analysis of body position, angle and force in lawn tennis service accuracy, Journal of Physical Education and Sport ${ }^{\circledR}(J P E S), 18(3), 1692-1698,2018$.

[2] Xavier, A. P., Ivo, F. F., Neto, L. B., \& Ervilha, U. F. Ball position during the tennis serve toss performed by junior athletes: Comparison between the first and second service. Journal of Physical Education and Sport, 17(1), 424-430, 2017.

[3] MAVVIDIS., MANOUSARIDOU., GRIVAS., EVAGELIDIS T., LAIOS, The effectiveness of serve in tennis depending on the placement of palm across the racket grip inwards or outwards, Journal of Physical Education and Sport, 14, 4, 576-580, 2014.

[4] Knudson D, Biomechanical Principles of Tennis Technique: using science to improve your strokes, Pennsylvania State University: Racket Tech Pub, 2011.

[5] Rive J. \& Williams S. C, Tennis Skills and Drills, Champaign: Human Kinetics. 2012.

[6] Cook, D. A., \& Artino, A. R. Motivation to learn: an overview of contemporary theories. Medical Education, 50 (10), 997-1014, 2016. https://doi.org/10.1111/medu.13074.

[7] Rina Ambar Dewanti, Beltasar Tarigan, Dian Budiana, Yudy Hendrayana, Lutfi Nur, "Developing a New Model of Resistance-based Strength Train and Its Effects on Junior Athletes' Tennis Serve Performance," International Journal of Human Movement and Sports Sciences, Vol. 8, No. 5, pp. 229 - 234, 2020. DOI: 10.13189/saj.2020.080510.

[8] Gusril. Penelitian Pengembangan dalam Ilmu Keolahragaan (Irfan, Ed.). Kencana, 2016.

[9] Hidayat, H. Design Model in the Context of Vocational Education and Training (VET)-NC-ND.Procedia-Social and Behavioral Sciences, 204, 206-211,2015. https://doi.org/10. 1016/j.sbspro.2015.08.142.

[10] Andika Adinanda Siswoyo, Agung Setyawan, Tyasmiarni Citrawati, Rita Prima Bendriyanti, Citra Dewi, "Management of Outdoor Learning Models for Environmental Education Courses," Universal Journal of Educational Research, Vol. 8, No. 11, pp. 5036-5043, 2020. DOI: $10.13189 /$ ujer.2020.081103.

[11] Casey, Ashley, Models-based Practice: Great White Hope or White Elephant, Physical Education and Sport Pedagogy 19 (1): 18-34, 2014. doi:10.1080/17408989.2012.726977.

[12] Dyson, Ben, Pamela Kulinna, and Mike Metzler, Introduction to the Special Issue: Models Based Practice in Physical Education. Journal of Teaching in Physical Education 35 (4): 297-298. doi:10.1123/jtpe, 2016.

[13] Hoskins-Burney, T., \& Carrington, Lex. The tennis drill book. Human Kinetics, 2014.

[14] Rive, Joey., \& Williams, S. Tennis skills \& drills. Human Kinetics, 2012.

[15] Silalahi, A. Development Research (Penelitian Pengembangan) Dan Research \& Development (Penelitian \& Pengembangan) Dalam Bidang Pendidikan/Pembelajaran, 2018. https://doi.Org/DOI:10.13140/RG.2.2.13429.88803/1. 